\title{
THE IMPACT OF RADIOCARBON DATING ON OLD WORLD ARCHAEOLOGY: PAST ACHIEVEMENTS AND FUTURE EXPECTATIONS
}

\author{
O Bar-Yosef \\ Peabody Museum, Department of Anthropology, Harvard University, Cambridge, Massachusetts 02138, USA. \\ Email: obaryos@fas.harvard.edu.
}

\section{INTRODUCTION}

Half a century since radiocarbon was first used in the archaeology of the Old World, it seems that the expectations of W F Libby may be becoming a reality. In 1952 (Libby 1952:97), he wrote:

Archaeologists, geologists and palynologists are continually searching for the means to improve methods of counting time. The . . . relative chronologies lack precision and direct correlation with the calendar, except when they may be checked with, ... for example, the calendar based on tree-ring counts.

Two achievements that have gone some way towards realizing this goal are the use of accelerator mass spectrometry (AMS) techniques (e.g. Taylor 1997) and of calibration curves (e.g. Stuiver et al. 1993, 1998). We are still only at the threshold of seeing the impact of these two crucial advances on some strongly debated archaeological issues.

Since the end of the 18th century, some basic questions that cannot be answered without accurate dates have been at the heart of archaeological research. Practice has demonstrated that the long sequence of human evolution, from the time hominids created durable remains, the early colonization of Eurasia or even the first dispersals of Modern humans, are beyond the upper reach of ${ }^{14} \mathrm{C}$ techniques.

During the last five decades, traditional ${ }^{14} \mathrm{C}$ dating techniques have made numerous contributions to the archaeology of the Old World. These are evidenced in a vast literature that reports and discusses the evolution of social and cultural entities recorded from over the last 40,000 years. Terminologies may vary across Eurasia and Africa, but in the most encompassing definitions, this is a world that shifted from foraging lifestyles to farming and herding modes of production, which were then followed by the emergence of urbanism and the ensuing industrial revolution.

During these 50 years, archaeologists, geoarchaeologists, and archeobotanists have used the services of an ever-increasing number of ${ }^{14} \mathrm{C}$ laboratories. In many of them, one notes a growing awareness of the need for the active participation of an experienced field archaeologist throughout the entire process, from collecting the samples and the gathering of relevant information, through laboratory operations, and the final evaluation and write-up of the results. While all this is known to the readers, and the contributions that are being made to various archaeological questions are important, there are, in the author's view, two major concerns in Old World archaeology that are of common interest to a majority of archaeologists and world historians. The advancements in dating these past events or processes will have a far-reaching impact on the interpretation of cultural history.

The two main problems are the transition from the Middle to the Upper Paleolithic, a cultural revolution which has also been labeled a "creative explosion" (Pfeiffer 1982), and the origin of plant cultivation in the two presumed centers of early agriculture, namely, the Levant in Western Asia and the middle Yangtze region of China. Precise dating of archaeological contexts and assemblages of plants and animal bones derived from well-excavated sites in these two centers will undoubtedly facilitate the resolution of long-lasting debates concerning the "where" and "when" issues of these events. The more controversial aspect of both inquiries, the "why" question, will undoubtedly 
remain open to scholarly opinions as diverse as there are approaches to world cultural history. Each of these major transitions is summarized below, followed by a brief discussion incorporating future expectations.

\section{The Middle to Upper Paleolithic Revolution}

Almost no one is seeking the origins of the Middle/Upper Paleolithic revolution in Western Europe, although everyone, including the media, is using the archaeological record from this region to characterize the differences between two populations-the Neandertals and Cro-Magnons. Most writers who present their views on this transition consider it to be a technological and cultural revolution (e.g. Gilman 1984; Gamble 1986; Mellars 1989; White 1989; Stringer and Gamble 1993; Mellars 1996a, 1996b; Mithen 1996; Marshack 1997; White 1997). A few follow the suggestion (Klein $1995,1999)$ that it was triggered by a neurological change in the "near-Modern Humans" some 50,000 years ago, which has recently gained further support from a genetic study (Quintana-Murci et al. 1999). However, there are others (e.g. Clark 1997; Straus 1997) who regard the transition as a gradual change that took place on a regional scale. Several scholars suggest that the latest West European Neandertals had demonstrated their innovative capacities before encountering the incoming Cro-Magnons. The arguments for one or another of the alternative interpretations rely heavily on the available ${ }^{14} \mathrm{C}$ dates, a proposed synchronization between TL, ESR and ${ }^{14} \mathrm{C}$ dates, and the drive to reach a calendrical chronology (D'Errico et al. 1998; Zilhão and D'Errico 1999a contra Mellars et al. 1999; see also Van der Plicht 1999 contra Van Andel 1998).

Elsewhere, I have suggested that by employing models that explain the Neolithic revolution we may gain insights into the techno-cultural revolution that occurred some 50,000-40,000 years earlier (Bar-Yosef 1992, 1994, 1998c). This analytical procedure would be similar to employing studies of the Industrial Revolution as sources for testing hypotheses concerning the Neolithic revolution.

The common denominators for all three of these revolutions include the emergence of new technology in a "core area," and its dispersal (with or without the cultural baggage) by migrating groups, or by diffusion. Study of the historical process can determine "where" and "when" techno-cultural changes occurred and how long it took for the ensuing diffusion, migration, and impacts to affect the neighboring regions. The "why" question remains within the domain of speculation. In all cases, the precise dates play an important role, and it is in this field that the various dating techniques can make major contributions.

Currently, there are only a few archaeological indications that East Africa (Ambrose 1998a, 1998b; Klein 1999), South Africa, the Nile Valley (Van Peer 1998), or the Levant (Sherratt 1997) may have been the original locus of the Middle/Upper Paleolithic revolution. Other proposals point in the direction of central Asia or Anatolia (e.g. Otte 1998). The paucity of field research in East Africa and dated sites in the Nile Valley, however, must leave all options open.

Most late Middle Paleolithic or Mousterian sites in the Levant and Northeast Africa are dated at 60 to 50/45 ka BP on the basis of thermoluminescence (TL) and electron spin resonance (ESR) measurements as well as ${ }^{14} \mathrm{C}$ dates $>46,000$ BP (Bar-Yosef et al. 1996; Bar-Yosef 1998a; Van Peer 1998). Culturally, the end of the Levantine Middle Paleolithic is marked by the appearance of Early Upper Paleolithic (EUP) assemblages in several sites (Figure 1). When assemblages of both periods are compared across the chronological boundary, the change seems to represent a technological revolution (e.g. Marks 1993; Bar-Yosef 1998c). The paucity of bone and/or antler objects and the rarity of marine shell beads from EUP contexts have made the lithic assemblages the main source of information. 


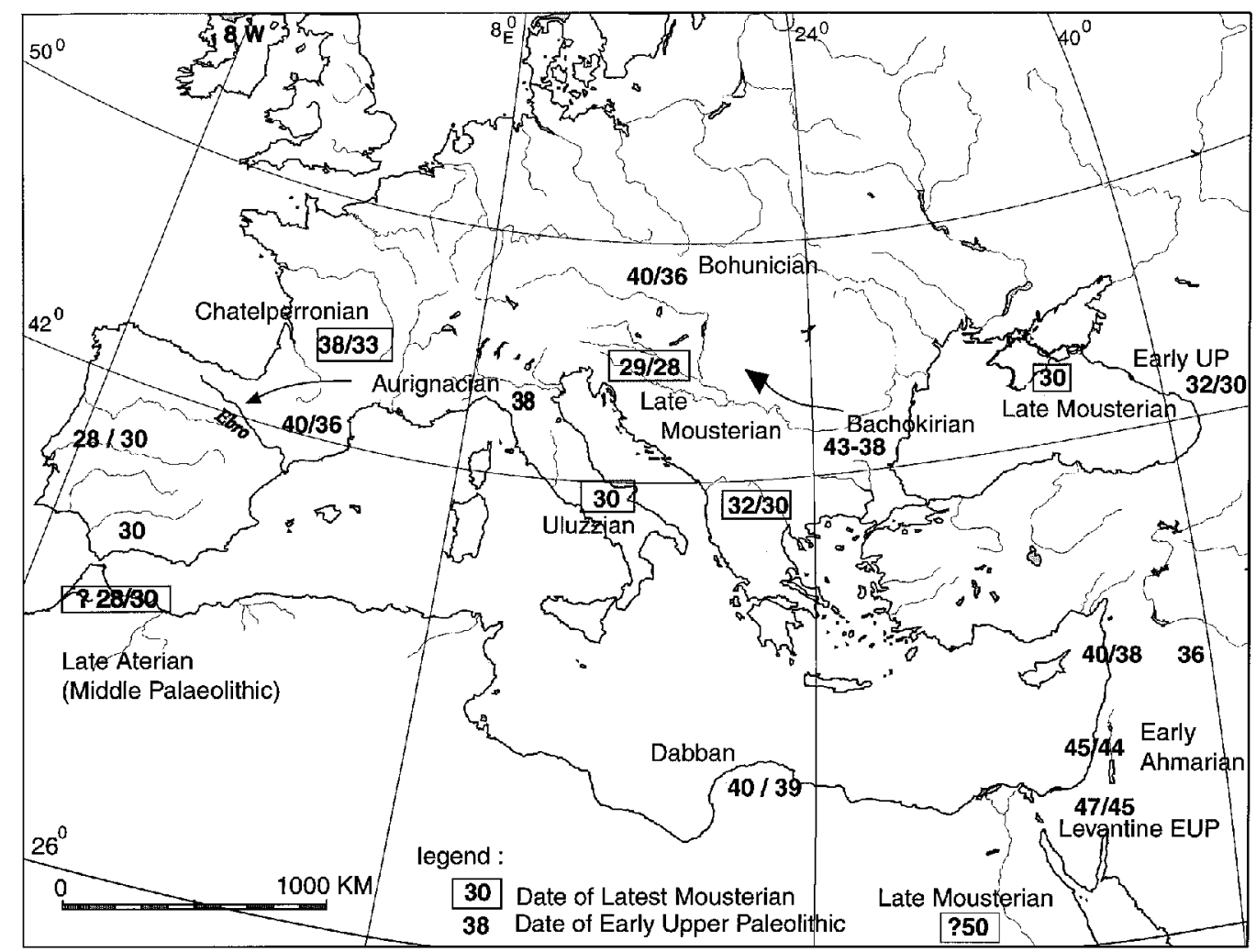

Figure 1 Map of Western Eurasia and North Africa indicating dates of the Latest Mousterian (in boxes) and Early Upper Paleolithic in various regions. The dates are a combination of TL, ESR, and radiocarbon uncalibrated readings.

The image of the pan-Levantine EUP lithic industries is rather complex, mainly due to the small number of sites, the chronological ambiguities (on which future work is required), and the presence of particular local tool types that make long distance correlations uncertain. The main sites are Ksar 'Akil (Lebanon), Emireh cave and Boker Tachtit (Israel), Umm el Tlel (Syria), and Üçagizli (Turkey) (Garrod 1955; Marks 1983; Ohnuma 1988; Bourguignon 1996; Kuhn et al. 1999).

Boker Tachtit, in the Negev Highlands, which dated to 47 and 46 ka BP (Marks 1983), has produced cores and their refitted blanks (Volkman 1983) that demonstrate the change in how the flint knappers conceived the volume of the flint nodule. Levallois points, typological markers of the late Mousterian, were now shaped by bi-directional detachments, thus differing from their predecessors. The shift in methods of stone tool production possibly responded to a change in hafting projectiles, and the invention of spear throwers. Other special projectile points are known as Emireh points-the common tool type in Emireh cave and Boker Tachtit.

In Ksar 'Akil, Lebanon, manufacturers preferred simpler points and special scrapers known as "chamfered pieces", where the working edge was shaped by a side blow (Newcomer 1970; Bergman et al. 1988; Ohnuma and Bergman 1990). Similar tools were found in Abri Antelias, a neighboring site with one Emireh point, and in Abu Halka, some $30 \mathrm{~km}$ further north. Interestingly, the EUP of Haua Fteah cave in Cyrenaica (Libya), named the Dabban culture, is also rich in chamfered pieces, 
although the precise nature of the relationship between the Libyan sites and those in Lebanon is as yet unknown (McBurney 1967).

In northeast Syria, the site of Umm el Tlel produced an industry of points and blades made by unidirectional percussion. All the stone tools are, without a doubt, from the Upper Paleolithic, although the special Emireh point and the chamfered pieces are absent (Bourguignon 1996). Interestingly, the AMS date for layer III2A is $34,530 \pm 750 \mathrm{BP}$ (Gif A-93216) and the TL date is $36 \pm 2.5 \mathrm{ka}$ (Gif A93215).

Additional assemblages were uncovered in Üçagizli and Kanal caves (Kuhn et al. 1999), where a blade-based industry resembles that of Umm el Tlel, with end scrapers, burins, and retouched blades. The presence of marine shell beads is noteworthy. Two AMS dates of 39,400 $\pm 1200 \mathrm{BP}$ (AA-27994) and 38,900 $\pm 1100 \mathrm{BP}(\mathrm{AA}-27995)$ place the assemblage from Üçagizli within the range of the EUP industries of the Levant.

It is generally agreed that ${ }^{14} \mathrm{C}$ dates earlier than $30,000 \mathrm{BP}$ should be considered as recording minimal ages. However, Van Andel (1998) has suggested that dates older than 38/39 ka BP are again closer to the real ages and do not underestimate the true age, as is the case for dates younger than $30 \mathrm{ka}$. Van der Plicht (1999) disagrees. Additional uncertainties arise from the use of different laboratories and the possible contamination of charcoal by bioturbation. In this respect, advancements in dating techniques in recent years should allow us to synchronize TL, ESR, and ${ }^{14} \mathrm{C}$ dates from late Middle and EUP sites in the Levantine sequence. Unfortunately, the size of the time difference between the uncalibrated ${ }^{14} \mathrm{C}$ years and TL and ESR years has various estimates. The proposal that ${ }^{14} \mathrm{C}$ dates in this range (earlier than $30 \mathrm{ka}$ ) are younger than the TL and ESR ages only by 3-4 ka (Mellars et al. 1999 and references therein), is in need of further testing. In one case, the ${ }^{14} \mathrm{C}$ dates from Umm el Tlel are only about 2 ka younger than the TL date, and lie within the standard deviation of the latter.

Another proposal to combine the results of the two dating techniques was undertaken in Kebara cave (Bar-Yosef et al. 1996). TL measurements place the upper part of the Mousterian sequence in Kebara at $48.3 \pm 3.5 \mathrm{ka}$ (Valladas et al. 1987), although there are no secure dates for the latest occupation. The EUP assemblages, which are definitely younger than the phase containing the Emireh points, were ${ }^{14} \mathrm{C}$ dated to $43 / 42 \mathrm{ka}$. It was therefore suggested that a cautious estimate of $46 / 45 \mathrm{ka}$ BP for the MP/UP transition seems reasonable, and the gap in the Kebara sequence from 46/45 ka to $43 \mathrm{ka}$ lends credence to the ${ }^{14} \mathrm{C}$ dates for the Boker Tachtit Level 1 (47 and $46 \mathrm{ka}$; Marks 1983).

Another option in dating the boundary between the Middle and the Upper Paleolithic in the Levant is to employ the dates available for the Ksar 'Akil sequence. Mellars and Tixier (1989), similarly to McBurney in his study of the cave of Haua Fteah (Libya), estimated the rate of sedimentation for this site. Eleven AMS readings of charcoal samples from Ksar 'Akil, in addition to the previously obtained ${ }^{14} \mathrm{C}$ dates, allowed them to estimate the cultural transition as taking place around $50 \mathrm{ka}$. Surprisingly, the U-series disequilibrium dates on two bone samples produced earlier, by scientists who cautioned against accepting them without reservation (Van der Plicht et al. 1989), provided similar results. The bone dates are given as "surface" and "bulk" material, and are as follows: for layer XXVI (youngest Mousterian level) $47 \pm 9 \mathrm{ka}(\mathrm{G}-88174 \mathrm{~S})$ and $19 \pm 5 \mathrm{ka}$ (G-88173B); and for layer XXXII (Mousterian) $51 \pm 4$ (G-88177S) and $49 \pm 5$ (G-88178B).

The situation in the Taurus and on the Anatolian plateau is poorly known (Yalçinkaya et al. 1993; Otte et al. 1995; Kozlowski 1998), with the exception of the latest Mousterian layers at Karain cave 
(Antalya province), which were ESR dated to $62.0 \pm 10.1$ to $71.6 \pm 11.4 \mathrm{ka}$ (EU), or $65.5 \pm 10.6$ to $74.4 \pm 11.8 \mathrm{ka}$ (LU) (Çetin et al. 1994). No dates are available for the EUP in this vast region.

The state of dating in the Zagros, where several cave sites have been excavated, is not much better (Solecki 1963, 1964; Dibble 1993; Dibble and Holdaway 1993; Solecki and Solecki 1993). The ${ }^{14} \mathrm{C}$ results of 46 and $50 \mathrm{ka}$ from layer D in Shanidar, where several of the Neandertal remains were uncovered, could be argued as simply minimal dates, or as indicating the persistence of the Middle Paleolithic in this mountainous region. The Upper Paleolithic industry known as the Baradostian is dated by a series of readings to 33-28 ka, and in Yafteh cave to the same range (Smith 1986). The absence of the EUP from this site and the other known caves lends temporary support to this interpretation. Further north, in the Caucasus region, similar Mousterian industries seem to be of the same, late age (Kozlowski 1998; Golovanova et al. 1999; Figure 1).

Broadening the geographic scope of the present overview, namely, the dating of the late Middle Paleolithic and EUP, introduces additional evidence for what may have been a patchy colonization of Cro-Magnons across Eurasia (Figure 1). In Crimea, producers of the Mousterian industry survived until $29 \mathrm{ka} \mathrm{BP}$, and the early EUP — dated to $30 \mathrm{ka} \mathrm{BP}$ - is interpreted as demonstrating a short coexistence of two populations (Marks and Chabai 1998; Rink et al. 1998). In Greece, the late Mousterian is dated to $32-30 \mathrm{ka} \mathrm{BP}$ by a series of ${ }^{14} \mathrm{C}$ dates from Theopetra cave in Thessaly, supported by the earliest dates for the EUP in Klisoura cave 1, in the Argolid (Karkanas 1999; Kyparissi-Apostolika 1999; Koumouzelis et al. forthcoming). The late survival of Neandertals is also evidenced in the direct dates of the human bones from Vindija cave in Croatia, which place these relics at $28 \mathrm{ka} \mathrm{BP}$ (Smith et al. 1999).

On the other hand, an EUP industry known as the Bohunician is dated in Bohemia to 40-36 ka BP (Svoboda and Simán 1989). Further west, the earliest Aurignacian in northeast Spain dates to 40-37 ka BP (e.g. Bischoff et al. 1989, 1994; Cabrera and Bernaldo de Quirós 1996; Straus 1996; Mellars et al. 1999). The persistence of the Mousterian in southern Italy (Kuhn and Bietti, forthcoming) and in Iberia south of the Ebro valley until about $30 \mathrm{ka} \mathrm{BP}$ is, in most cases, founded on numerous ${ }^{14} \mathrm{C}$ dates for the late Mousterian and EUP (Raposo and Santonja 1995; Barton et al. 1999; Zilhão and D'Errico 1999a, 1999b; Carbonell et al. forthcoming). Figure 1 presents an overall geographic summary. Although boundaries between the Neandertal and Cro-Magnon territories are not marked, the question is raised of whether Neandertal populations across southern Europe continued to be in touch with each other after 40-38 ka BP, or became isolated groups. Small populations, as modeled by Zubrow (1989), if not intermarrying with incoming groups, could disappear within a relatively short period.

There is little doubt today that the rapid cultural changes through the Upper Paleolithic times reflect the results of a major revolution. There were significant technological and social changes, but they are not easy to decipher, due to the grosgrain of chronological resolution as presented above. As with other revolutions, the nature of the changes is better documented after a certain lapse of time, when the new cultural expressions stand in contrast to those of pre-revolutionary times. In the case of the European sequence, the proliferation of lithic blade industries, antler and bone tools, mobile art objects, and cave art (in the Franco-Cantabrian region) gives a good example. In the Near Eastdespite the more ephemeral character of the Upper Paleolithic sites-the evolved blade technology, the appearance of grinding tools, and the modest use of bone, antler and marine shells mark the cultural shift. That the change was rapid is clearly demonstrated by the radiometric scale. From 270/ $250 \mathrm{ka}$ through 48/46 ka BP, Mousterian lithic industries were pre-eminent, while from 45/42 ka BP 
onwards, laminar industries formed the basic stone tool-kits, and involved the use of various raw materials, while the appearance of imagery was seen.

\section{Origins of Agriculture in Western Asia}

The agricultural revolution, or as it is known in the archaeological literature, the "Neolithic Revolution", is a topic that has attracted historians, archaeologists and botanists since the 19th century. The impact of plant cultivation by sedentary communities on human diets and rates of reproduction is considered the crucial threshold that caused rapid population growth in many parts of the world during the Holocene (e.g. Bar-Yosef 1998c; Cohen 1977; Harris 1998a, 1998b; Smith 1998).

As with all important past revolutions, the emergence of plant cultivation some 11,000 years ago, followed by animal domestication, is evaluated on the basis of its outcome. Gradualists see the cultural and socio-economic changes as a slow process that took thousands of years to complete. Others view the change as radical and rapid. The question of "why" a particular change took place is often the most debated. Once there are records based on field and laboratory observations, however, archaeologists tend to agree on the "when" and "where" aspects of the studied revolution. It is in both these aspects that AMS ${ }^{14} \mathrm{C}$ measurements, especially when calibrated, can revolutionize past understandings and pose additional challenges.

The Fertile Crescent of western Asia and the Yangtze River valley are considered the two oldest centers of the transition to agriculture in the Old World (Smith 1998). Like other major revolutions in history, the Neolithic revolution began in a core area. The locus of early cultivation practiced by Neolithic villagers is still uncertain. Past hypotheses placed incipient farming in the natural habitat of cereals (Braidwood 1975), or at the edges of the main distribution of the progenitors, namely, in the marginal belt where foragers experienced decreasing yields in plant food resources in the face of prolonged worsening of environmental conditions (e.g. Binford 1968; Flannery 1973).

Archeobotanical evidence of carbonized plant remains from Neolithic sites in the Levant points to the location in which cultivation began (e.g. Harris and Hillman 1989; Miller 1992, 1997; Hillman 1996; Heun et al. 1997; Harris 1998a). There is little doubt today that systematic cultivation and harvesting in the same fields year after year resulted in the domestication of plant species (Zohary 1989; Zohary and Hopf 1994; Bar-Yosef and Meadow 1995; Harris 1996a, 1996b, 1998b). Once communities of cultivating foragers were established, the domestication of goats and sheep was initiated (Legge 1996), followed later by cattle and pigs (Uerpmann 1989).

The search for the earliest farming communities began with the pioneering project of $\mathrm{R}$ Braidwood (1952, 1973, 1983), which targeted the hilly flanks of the Zagros, where wild cereal species grow today. His choice relied on botanical surveys that mapped the distribution of the various Cerealia species across western Asia (Harlan and Zohary 1966; Harlan 1977; Zohary and Hopf 1994). Unfortunately, at the time these surveys were conducted, the impact on the vegetation of Terminal Pleistocene-Early Holocene climatic fluctuations was not taken into account, a fact realized only later (Wright Jr 1993).

In the late 1990s, archaeologists and archeobotanists began to create an evolutionary scenario based on various kinds of data sets. First, information retrieved from pollen cores and the deep-sea cores from the Eastern Mediterranean provides the distribution of the paleo-phytogeographical belts (Van Zeist and Bottema 1991; Roberts and Wright Jr 1993; Baruch 1994; Bottema 1995; RossignolStrick 1995, 1997; Hillman 1996). Adopting the correction for hard-water effects on ${ }^{14} \mathrm{C}$ dates in inland lakes, proposed by Rossignol-Strick (1995), established sound correlations between marine 
and terrestrial pollen cores. According to this scheme, the Younger Dryas is signified by the abundance of Chenopodiaceae, followed by an increase in deciduous oak pollen that marks the early millennia of the Holocene and reflects the increase in annual precipitation.

Second, there is a general agreement on the identification of the Younger Dryas, whether in marine sediments, lake cores, or speleothems (Wright Jr 1993; Rossignol-Strick 1995; Hillman 1996; Landmann et al. 1996; Bar-Mathews et al. 1997, 1999; Lemcke and Sturm 1997; Fontugne et al. 1999; Frumkin et al. 1999). The conditions prevailing during the Younger Dryas are crucial in interpreting the archaeological remains, and, unfortunately, the dating of this period in the Near East is not without difficulties. According to the ice cores, the Younger Dryas lasted from 12.9 to $11.6 \mathrm{ka}$ (Alley et al. 1993; Mayewski et al. 1996), while in the varve sequence of Lake Van in eastern Turkey (Lemcke and Sturm 1997), this cold and dry period was longer by around 800 years.

The third source of data is carbonized plant remains, which indicate "where" within the region various seeds were collected (Hillman et al. 1989; Hillman 1996; Kislev 1997). The seeds, if in secure archaeological context, often provide more precise dates for the "when" question, especially through AMS measurements. Although the number of directly dated seeds is currently rather small, the growing awareness among archaeologists and archeobotanists that this is the way forward facilitates the testing of several hypotheses in the near future. Meanwhile, available charcoal dates already provide an interesting picture, whether at the level of a particular site, or across a microregion such as the Jordan Valley (Figures 2-5).

A brief summary of the paleoclimatic sequence of the Terminal Pleistocene, following the Last Glacial Maximum (LGM), would begin with an increase of annual precipitation and a slow temperature rise from around 15,500 BP. The typical eastern Mediterranean cycle of wet, cold winters and dry, hot summers was established during this period and not later, as was suggested previously (McCorriston and Hole 1991; Wright Jr 1993). The rapid expansion of oaks (mainly the deciduous $Q$. ithaburensis), olives, and pistachio (which is always misrepresented in the samples due to low pollen production), as well as the cereals, which were present in the region from 19,000 BP, testify to this annual climatic pattern (Baruch and Bottema 1991).

The ensuing changes are recorded in the terrestrial pollen diagrams and were plotted fairly recently by Hillman (1996) as two vegetation maps for Western Asia, for 13 and $11 \mathrm{ka}$ BP (uncalibrated), respectively. These maps, although based on the terrestrial pollen cores (see above), demonstrate the expansion of three plant associations as follows: 1) forests and woodland in the Mediterranean coastal plain and hilly ranges, 2) oak-terenbinth, a mosaic of woodland and open areas dominated by annual grasses further inland, and 3) terenbinth-almond woodland-steppe that phases into the desertic Saharo-Arabian associations (Zohary 1973).

The natural stands of wild cereals are within the last two belts and often appear as grasses in the oak parkland. The expansion of the Mediterranean vegetation and especially of the natural habitats of the cereals resulted from increases in rainfall and temperatures. The prevailing climatic conditions of the Bölling/Allerød (ca. 15,000-13,000 cal BP) favored the growth of C3 plants (Sage 1995), used by Levantine foragers from at least 19,000 BP onwards (Kislev et al. 1992). The improved conditions seem to have served as an impetus for intensive exploitation of cereals and legumes, as well as fruit trees and acorns. The archaeological evidence indicates an increase in sedentism, a broad-based economy relying on extensive exploitation, and the emergence of a complex hunter-gatherer society known as the Natufian culture (Figures 2-3; Henry 1989; Belfer-Cohen 1991; Bar-Yosef 1998b). 


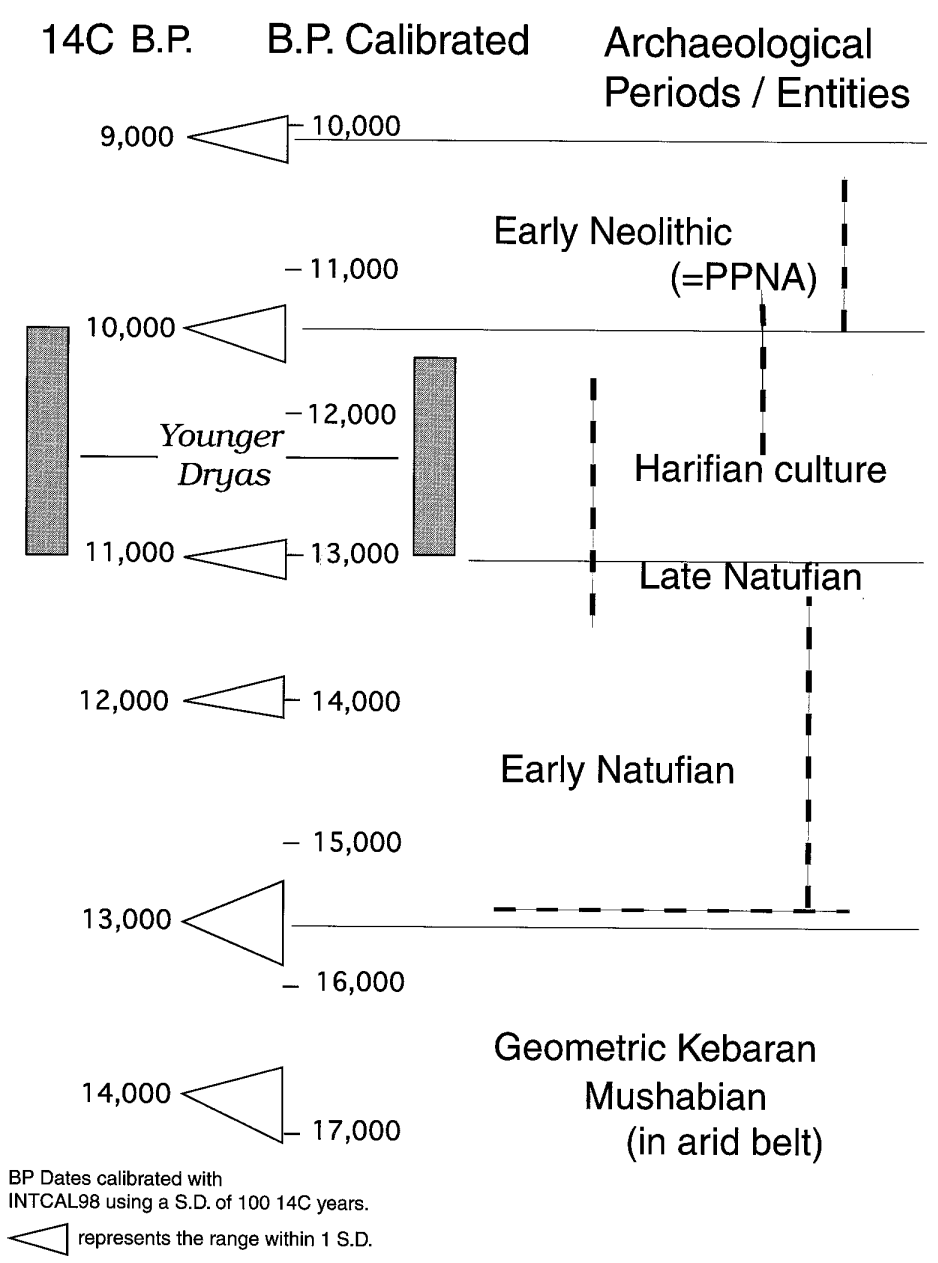

Figure 2 Calibrated generalized chronology for the Terminal Pleistocene and Early Holocene of the Levant, indicating both uncalibrated and calibrated BP dates. The figure demonstrates that the Earliest Neolithic actually began during the Younger Dryas.

The proliferation in recent years in the number of ${ }^{14} \mathrm{C}$ dates reveals that the dry and cold climate of the Younger Dryas was probably the main cause for the initiation of systematic cultivation (Bar-Yosef and Belfer-Cohen 1992; Moore and Hillman 1992; Bar-Yosef 1998a; Hole 1998). The crisis of the Younger Dryas, which lasted for about $1300 \pm 70$ yr (Alley et al. 1993; Mayewski et al. 1993), was due to its effect on the vegetation of Western Asia. It stopped the advance of the woodland into higher altitudes inland (in the Taurus and Zagros Mountains) and reduced the belt of oak and terenbinth. This reconstructed scenario is supported by the identification of carbonized plant remains from Mureybet (Van Zeist 1986; Van Zeist and Bakker-Herres 1986) and Abu Hureyra (Hillman et al. 1989; Moore and Hillman 1992; Figures 3-5), where cereals decreased; and Halan Çemi, which, on a more eastward tributary of the Tigris, by that time had no cereals present (Rosenberg et al. 1995).

Human acts are seen as the results of social decisions. It is hypothesized that the determining decision in favor of intentional cultivation was taken in the face of decreasing yields of cereals in the wild 
stands, in combination with the recognition that other economic solutions, such as becoming more mobile, given the regional population densities, were not the optimal way to minimize risk. The assumed depletion in the natural yields is a testable hypothesis. It relies on the slight decrease in atmospheric $\mathrm{CO}_{2}$ values during the Younger Dryas as the limiting factor in the distribution of the oakterenbinth belt, and in particular, in the declining annual returns among $\mathrm{C} 3$ plants such as the cereals, which had become a major source of carbohydrates for Levantine foragers (Bar-Yosef and Meadow 1995). The paleo-phytogeographical reconstruction points to a relatively narrow strip in the Levant in which the progenitors of most cereal species grew (Hillman 1996). This belt, although a series of delineated areas (Van Andel and Runnels 1995) also known as the "Levantine Corridor," became the locus in Western Asia in which the first agricultural communities were founded (Figure 4; Bar-Yosef and Meadow 1995; Bar-Yosef 1998c). The decision for economic change was probably not an easy one. It entailed the re-organization of the division of labor, seasonal scheduling of work, allocation of energy expenditure at different times of the year, and the like. However, the stable provision of a staple food meant an increase in the fertility rates, which, despite rising infant and toddler deaths (evidenced in burials), resulted in relatively rapid population growth (Bentley et al. 1993; Bentley 1996).

The return to increasing $\mathrm{CO}_{2}$ levels and higher annual amounts of precipitation during the early Holocene provided conditions suitable for successful cultivation (e.g. Araus et al. 1999). Hence, early farming communities-known archaeologically in the Levant as Pre-Pottery Neolithic A (PPNA) — and particularly their descendants_-during the Pre-Pottery Neolithic B (PPNB)—flourished (Figure 5). The ensuing off-shoot villages resulted in emigration and demic-diffusion into Europe, the Mediterranean islands, northeast Africa, and southern and central Asia (Ammerman and Cavalli-Sforza 1984; Wetterstrom 1993, 1998; Van Andel and Runnels 1995; Meadow 1998). At the same time, the wetter and warming climate of the early Holocene facilitated the larger geographic dispersal of the wild-cereal progenitors, at later times reaching the current distribution.

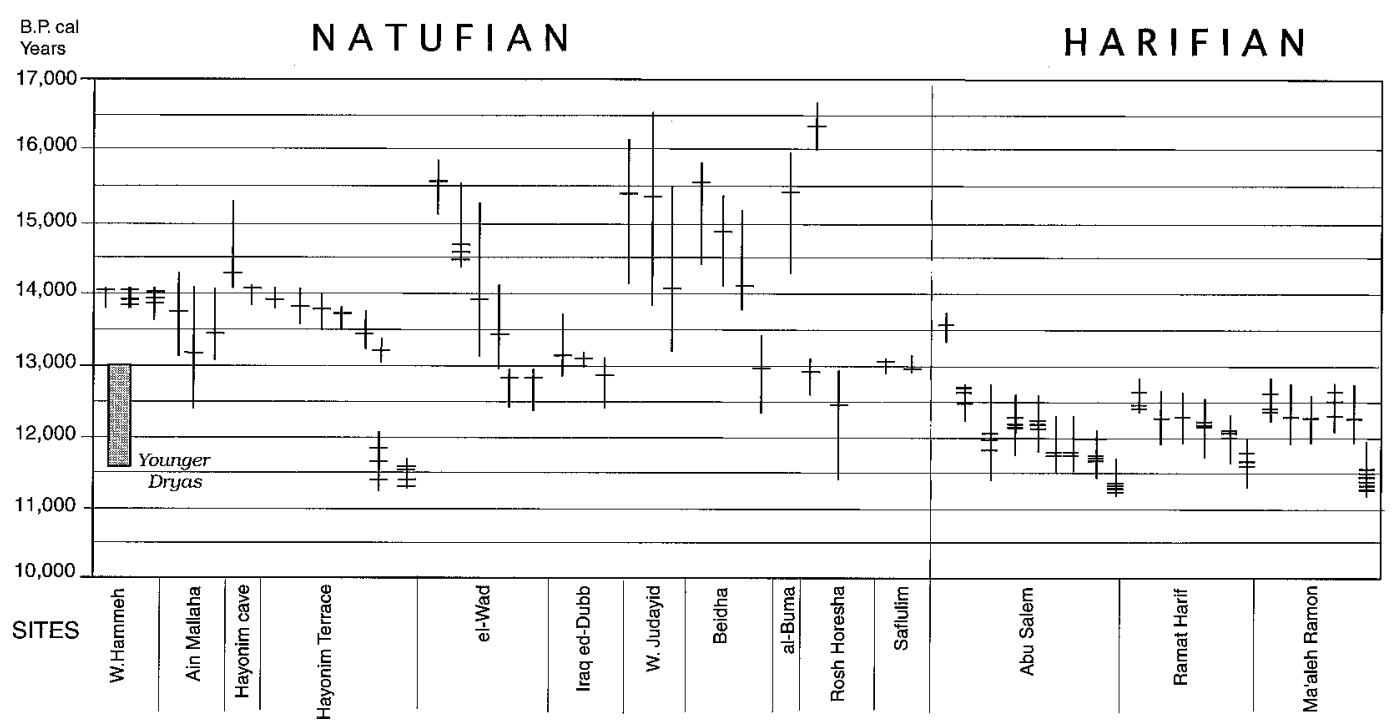

Figure 3 Calibrated dates for the Natufian (both Early and Late) and the Harifian (a desertic entity in the Negev and northern Sinai). A general correlation between the onset of the Bölling/Allerød and the emergence of the Natufian culture is suggested, as is the contemporaneity of the Natufian and Harifian with the Younger Dryas. 


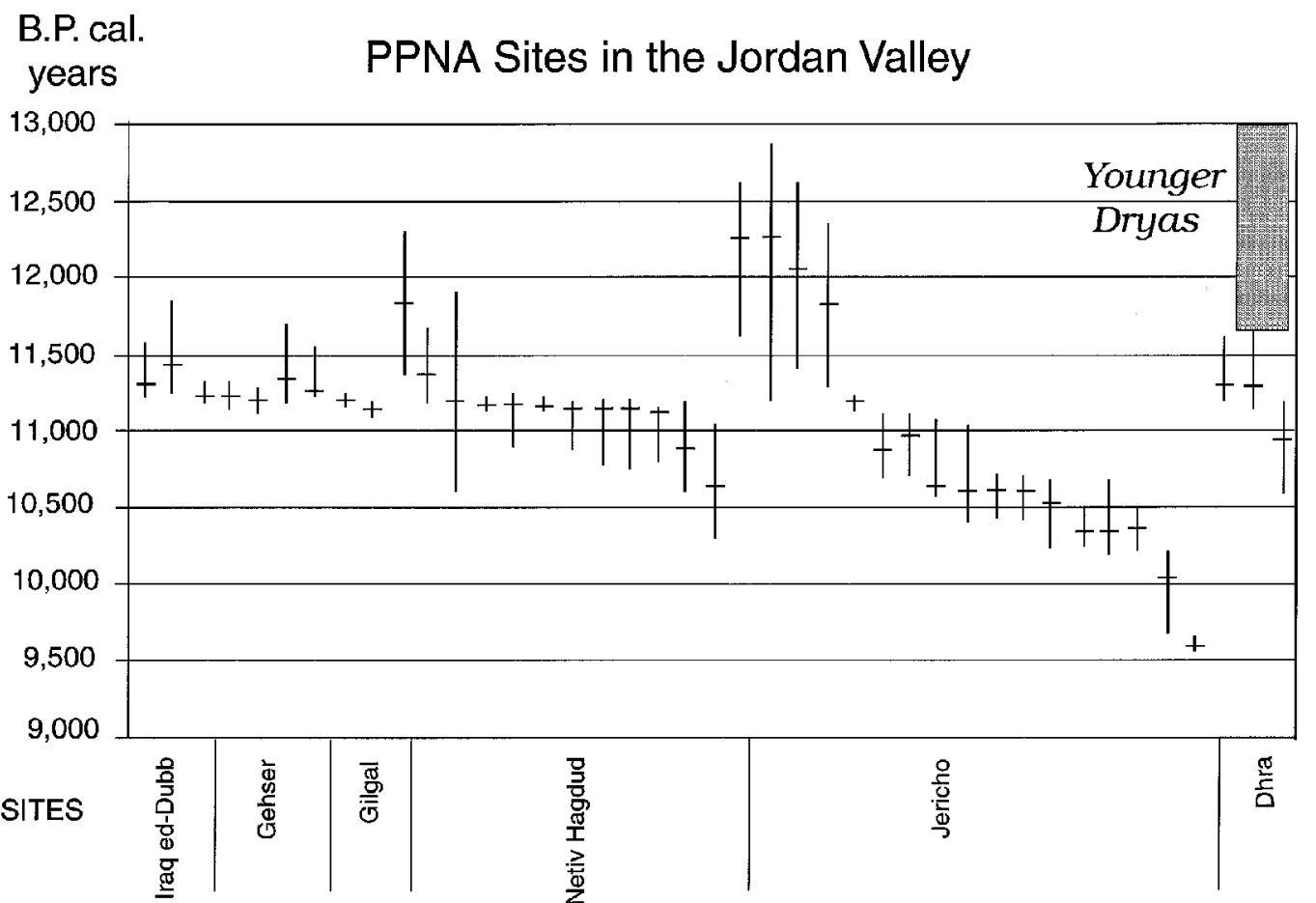

Figure 4 Calibrated dates of Early Neolithic sites in the Jordan Valley and the neighboring hilly areas indicate that the large communities such as Jericho, Netiv Hagdud, and Gilgal were probably the result of the emergence of intentional cultivation during or immediately at the end of the Younger Dryas.

\section{DISCUSSION}

In the previous sections, only two issues from the endless number of archaeological investigations were chosen for presentation. In both cases the demand and need for accurate dating have a major impact on the social interpretation of the data. However, there are other domains in which AMS ${ }^{14} \mathrm{C}$ measurements seem to revolutionize our interpretations, and one of these is the study of cave art. This is not only a subject that continues to interest specialists, but is also a topic in art history, and continues to be studied by students of human cognition and its intricate evolution. Even a cursory survey will demonstrate that brain scientists and social psychologists, among others, cite and interpret prehistoric cave art (mostly from the Franco-Cantabrian region) as evidence for symbolic behavior. In addition, mobile objects that fall under the category of imagery are being considered as such (e.g. Marshack 1972, 1997; Donald 1991; Mithen 1996; Conkey et al. 1997; Deacon 1997; Klein 1999). It is, therefore, worth noting that direct AMS dating of samples carefully removed from paintings has enabled investigators to test previous hypotheses concerning their age, and in particular, to confirm that the earliest cave paintings, in the site of Grotte Chauvet, date back to 32-30 ka and in Cosquer Cave to 28-26 ka (Clottes et al. 1995; Clottes 1996a, 1996b). These dates tally well with the even older mobile art objects and body decorations known from the Aurignacian, and support the contention that this culture differs entirely from the Mousterian and thus signifies the techno-cultural revolution of the Middle to Upper Paleolithic.

Another well-known historical example is the dating of the famous Shroud stored in the Cathedral of St John the Baptist in Turin, Italy. In this case, the three series of AMS dates carried out indepen- 
dently by three laboratories support the history of this object as first noted in the mid-14th century AD. The calibrated ${ }^{14} \mathrm{C}$ dates suggested a range of the late 13 th to 14 th centuries AD (Damon et al. 1989; Taylor 1997).

The calibration of conventional ${ }^{14} \mathrm{C}$ ages has already had some major impacts in archaeology. The first all-encompassing attempt to evaluate the impact of the calibration curve on archaeological interpretations was made by Renfrew (1973). In this influential survey, the chronological paradigm of G Childe-which was based on artifact and assemblage correlations across the Mediterranean and Europe-was used, with the Egyptian timetable as a basic yardstick. However, when the available ${ }^{14} \mathrm{C}$ dates for various cultural manifestations from Greece through Britain were calibrated, non-diffusionist explanations were put forward. Today, correlations between Egypt and Greece are considered well established. Models based on diffusion and migrations are back in fashion (e.g. Anthony 1990), and like other explanations, propose that the expansion of farming from the Near East to Western Europe can be correlated with the dispersal of Indo-European languages (Renfrew 1987).

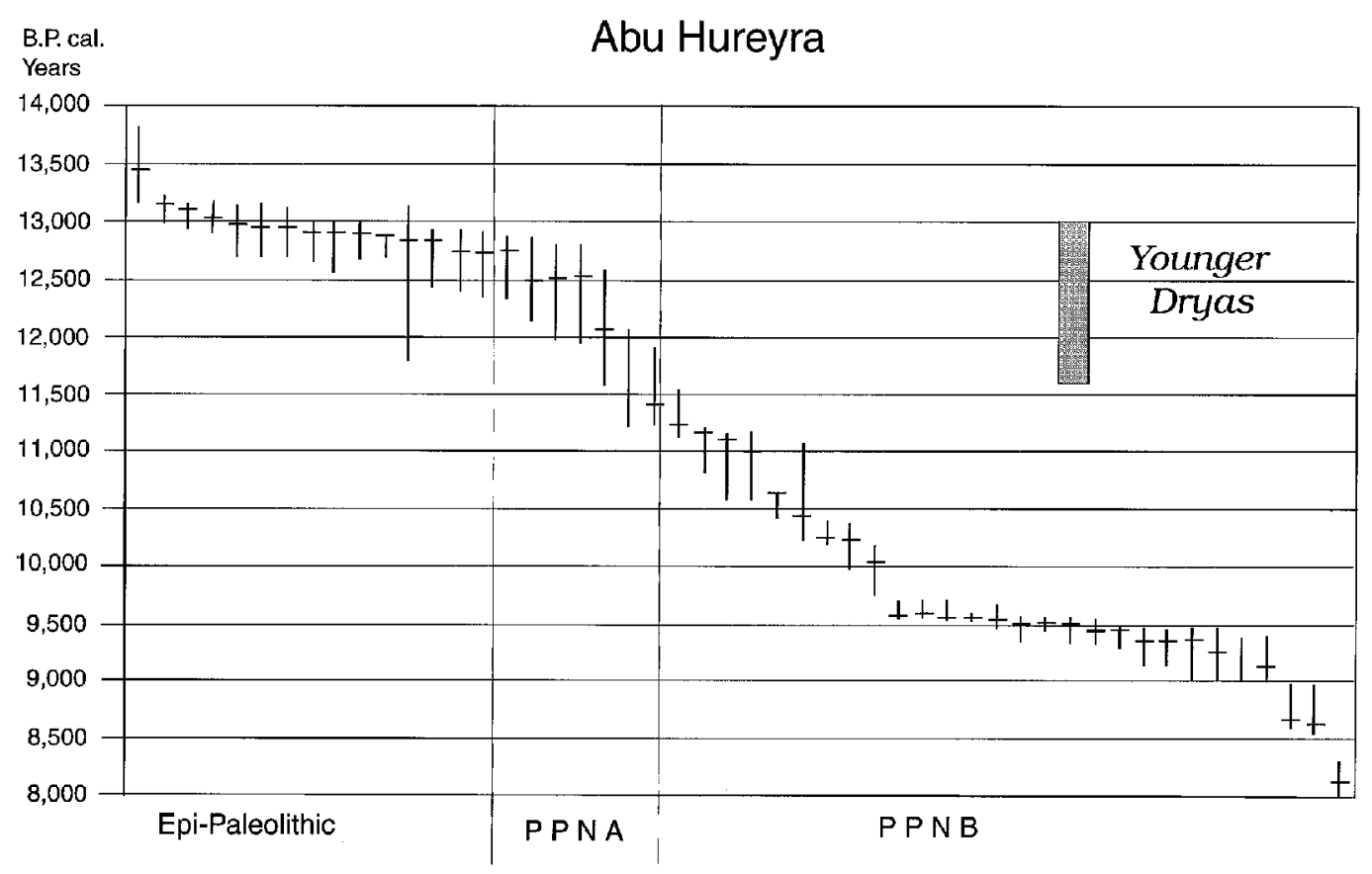

Figure 5 The radiocarbon calibrated chronology of Abu Hureyra on the Middle Euphrates River (Moore et al. 1986), from which carbonized plant assemblages were recovered. The dates indicate that the emergence of the farming community was either during or at the beginning of the PPNB.

Chronologies earlier than the third millennium BC in the Near East are dependent on ${ }^{14} \mathrm{C}$ dates. Time estimates employed by archaeologists to evaluate whether a socioeconomic or cultural change was rapid or slow relied until now on non-calibrated ${ }^{14} \mathrm{C}$ dates. Correlations with Ice Core chronology, which is calendrical, require the calibration of dates derived from archaeological contexts. This would, for example, be the only way to test hypotheses that climatic changes triggered cultural changes in a given region. However, everyone who uses the calibration curve is familiar with the existence of "plateaux" when even a date with a rather small standard deviation could indicate several potential calendrical dates (e.g. Hajdas et al. 1995). Unfortunately, the time of the origins of agriculture also seems to coincide with one of these plateaux. 
Archaeologists should be able, in forthcoming years, to resolve the issue of chronological ambiguities. A potential way to overcome the problem of a "plateau" in the calibration curve is to obtain past climatic information from well-stratified, dated samples. Previous work has demonstrated that carbonized plants preserve the original ratios of ${ }^{16} \mathrm{O} /{ }^{18} \mathrm{O}$ and ${ }^{12} \mathrm{C} /{ }^{13} \mathrm{C}$ (Marino and DeNiro 1987; Marino and McElroy 1991). Similar investigations in the Near East provided promising results. For example, wood samples from the first century AD rampart in Masada, or on carbonized cereal grains from PPNB Tel Halula indicate the wetter climate or higher level of water availability during the lifetime of the plants (Araus et al. 1999; Yakir et al. 1994). This approach requires that carbonized seeds be collected with special attention paid to their stratigraphic position from sites that span the time of the Late Natufian and Early Neolithic, that is, from 13,000 to about 10,000 BP (calibrated). The isotopic information from a stratified sequence could be then compared with the climatic curve of the ice cores, although it is expected that the ${ }^{14} \mathrm{C}$ dates will fluctuate between older and younger readings (e.g. Hajdas et al. 1998). Such a research project would force archaeologists to indulge in an as yet very uncommon standard of behavior: that of publishing the sections of the sites and indicating from where the samples were taken (see for example Bar-Yosef et al. 1996). This kind of information, when accompanied by a report on the site's micromorphology, a study that would clarify the amount of disturbance, often of biogenic origins, would enable readers to evaluate the integrity of the so-called "archaeological context" (Courty et al. 1989; Goldberg and Bar-Yosef 1998). The cumulative experience of field archaeologists indicates that "clean" contexts are not easy to trace in Early Neolithic sites, however, given their potential in resolving important historical questions, the additional efforts would be worthwhile.

In sum, the last decade of ${ }^{14} \mathrm{C}$ dating has already made a significant impact on archaeological and historical interpretations. In an atmosphere of improved cooperation between scientists and archaeologists, new avenues of research can bring us revolutionary answers to old questions.

\section{REFERENCES}

Alley RB, Meese DA, Shuman CA, Gow AJ, Taylor KC, Grootes PM, White JWC, Ram M, Waddington ED, Mayewski, PA. 1993. Abrupt increase in Greenland snow accumulation at the end of the Younger Dryas event. Nature 362:527-9.

Ambrose SH. 1998a. Chronology of the Later Stone Age and food production in East Africa. Journal of Archaeological Science 25:377-92.

Ambrose SH. 1998b. Late Pleistocene human population bottlenecks, volcanic winter, and differentiation of modern humans. Journal of Human Evolution 34(6): 623-51.

Ammerman AJ, Cavalli-Sforza, LL. 1984. The Neolithic transition and the genetics of populations in Europe. Princeton: Princeton University Press. 176 p.

Anthony DW. 1990. Migration in archaeology: the baby and the bathwater. American Anthropologist 92(4): 895-914.

Araus JL, Febrero A, Catala M, Molist M, Voltas J, Romagosa I. 1999. Crop water availability in early agriculture: evidence from carbon isotope discrimination of seeds from a tenth millennium BP site on the Euphrates. Global Change Biology 5:201-12.

Bar-Yosef O. 1992 The role of Western Asia in modern human origins. Philosophical Transactions of the
Royal Society, B (London) 337:193-200.

Bar-Yosef O. 1994. The contributions of southwest Asia to the study of the origin of modern humans. In: Nitecki MH, Nitecki DV, editors. Origins of Anatomically Modern Humans. New York: Plenum Press. p 23-66.

Bar-Yosef, O. 1998a The Chronology of the Middle Paleolithic of the Levant. In: Akazawa T, Aoki K, BarYosef $\mathrm{O}$, editors. Neandertals and modern humans in western Asia. New York: Plenum Press. p 39-56.

Bar-Yosef O. 1998b. The Natufian culture in the Levant-threshold to the origins of agriculture. Evolutionary Anthropology 6(5):159-77.

Bar-Yosef O. 1998c. On the nature of transitions: the Middle to Upper Palaeolithic and the Neolithic Revolution. Cambridge Archaeological Journal 8(2):14163.

Bar-Yosef O, Arnold, M, Belfer-Cohen A, Goldberg P, Housley R, Laville H, Meignen L, Mercier N, Vogel JC, Vandermeersch B. 1996. The dating of the Upper Paleolithic layers in Kebara Cave, Mount Carmel. Journal of Archaeological Science 23:297-306.

Bar-Yosef O, Belfer-Cohen A. 1992. From foraging to farming in the Mediterranean Levant. In: A. Gebauer B, Price TD, editors. Transitions to agriculture in pre- 
history. Madison: Prehistory Press. p 21-48.

Bar-Yosef O, Meadow RH. 1995. The origins of Agriculture in the Near East. In Price TD, Gebauer AB, editors. Last hunters, first farmers: new perspectives on the prehistoric transition to agriculture. Santa Fe: School of American Research Press. p 39-94.

Barton RNE, Currant AP, Fernandez-Jalvo Y, Finlayson JC, Goldberg P, Macphail R, Pettitt PB, Stringer CB. 1999. Gibraltar Neanderthals and results of recent excavations in Gorham's, Vanguard and Ibex Caves. Antiquity 73(279):13-23.

Baruch U. 1994 The late Quaternary pollen record of the Near East. In: Bar-Yosef O, Kra RS, editors. Late Quaternary chronology and paleoclimates of the eastern Mediterranean. Tucson and Cambridge: Radiocarbon and the Peabody Museum of Archaeology and Ethnology, Harvard University. p 103-20.

Baruch U, Bottema S. 1991. Palynological evidence for climatic changes in the Levant ca. 17,000-9,000 B.P. In: Bar-Yosef O, Valla FR, editors. The Natufian culture in the Levant. Ann Arbor: International Monographs in Prehistory. p 11-20.

Belfer-Cohen, A. 1991 The Natufian in the Levant. Annual Review of Anthropology 20:167-86.

Bentley GR. 1996. How did prehistoric women bear "Man the Hunter"? Reconstructing fertility from the archaeological record. In Wright RP, editor. Gender and archaeology. Philadelphia: University of Pennsylvania. p 23-51.

Bentley GR, Goldberg T, Jasienska G. 1993. The fertility of agricultural and non-agricultural traditional societies. Population Studies 47:269-81.

Bergman CA, McEwen E, Miller R. 1988. Experimental archery: projectile velocities and comparison of bow performances. Antiquity 62(237):658-70.

Binford SR. 1968. Early Upper Pleistocene adaptations in the Levant. American Anthropologist 70(4):70717

Bischoff JL, Ludwig K, Garcia JF, Carbonell E, Vaquero M, Stafford TW Jr, Jull AJT. 1994. Dating of the basal Aurignacian sandwich at Abric Romaní (Catalunya, Spain) by radiocarbon and Uranium-series. Journal of Archaeological Science 21(4):541-52.

Bischoff JL, Soler M, Maroto J, Julià R. 1989. Abrupt Mousterian/Aurignacian boundary at c. $40 \mathrm{ka} \mathrm{bp:} \mathrm{Ac-}$ celerator ${ }^{14} \mathrm{C}$ dates from L'Arbreda Cave (Catalunya, Spain). Journal of Archaeological Science 16:563-76.

Bottema S. 1995. Holocene vegetation of the Van area: Palynological and chronological evidence from Sögütlü, Turkey. Vegetation History and Archaeobotany 4:187-93.

Bourguignon L. 1996 Un Mousterien tardif sur le site d'Umm el Tlel (Bassin d'El Khowm, Syrie)? Exemples des niveaux IIBase' et III2A'. In: Carbonell E, Vaquero M, editors. The last Neandertals, the first anatomically modern humans. Tarragona: Universitat Rovira i Virgili. p 317-36.
Braidwood RJ. 1952. The Near East and the foundations for civilization. Eugene: Condon Lectures, Oregon State System of Higher Education.

Braidwood RJ. 1973. The early village in Southwestern Asia. Journal of Near Eastern Studies 32(1-2):34-9.

Braidwood RJ. 1975. Prehistoric men. 8th edition. Glenview (Illinois): Scott, Freeman and Company.

Braidwood RJ. 1983. The Hilly Flanks and beyond: essays on the prehistory of southwestern Asia presented to Robert J. Braidwood, November 15, 1982. Chicago: Oriental Institute of the University of Chicago.

Cabrera V, Bernaldo de Quirós F. 1996. The origin of the Upper Palaeolithic: a Cantabrian perspective. In: Carbonell E, Vaquero M, editors. The last Neandertals, the first anatomically modern humans. Tarragona: Universitat Rovira i Virgili. p 251-65.

Carbonell E, Vaquero M, Maroto J, Rando JM, Mallol C. A Geographic Perspective on the Middle to Upper Paleolithic Transition in the Iberian Peninsula. In: BarYosef O, Pilbeam D, editors. The geography of Neandertals and modern humans in Europe and the Greater Mediterranean. Cambridge: Peabody Museum Press. Forthcoming.

Çetin O, Özer AM, Wieser A. 1994. ESR dating of tooth enamel from Karain excavation (Antalya, Turkey). Quaternary Geochronology (Quaternary Science Reviews) 13:661-9.

Clark GA. 1997. The Middle-Upper Paleolithic transition in Europe: an American perspective. Norwegian Archaeological Review 30:25-53.

Clottes J. 1996a. Recent studies on Palaeolithic art. Cambridge Archaeological Journal 6(2):179-89.

Clottes J. 1996b. Thematic changes in Upper Palaeolithic art: a view from the Grotte Chauvet. Antiquity 70:27688.

Clottes J, Chauvet J-M, Brunel-Deschamps E, Hillaire C, Daugas J-P, Arnold M, Cachier H, Evin J, Fortin P, Oberlin C. 1995. Les peintures paléolithiques de la Grotte Chauvet-Pont-d'Arc, à Vallon-Pont-d'Arc (Ardèche, France): datations directes et indirectes par la méthode du radiocarbone. Comptes-rendus de l'Académie des Sciences de Paris 320(IIa):1133-40.

Cohen MN. 1977. The food crisis in prehistory: overpopulation and the origins of agriculture. New Haven: Yale University Press.

Conkey MW, Soffer O, Stratmann D, Jablonski NG, editors. 1997. Beyond art: Pleistocene image and symbol. San Francisco: California Academy of Sciences.

Courty MA, Goldberg P, Macphail R. 1989. Soils and micromorphology in archaeology. Cambridge: Cambridge University Press.

D’Errico F, Zilhão J, Julien M, Baffier D, Pelegrin J. 1998. Neanderthal acculturation in Western Europe? A critical review of the evidence and its interpretation. Current Anthropology 39 (Supplement):S1-S44.

Damon PE, Donahue DJ, Gord BH, Hatheway AL, Jull AJT, Linick TW, Sercelo PJ, Toolin LJ, Bronk CR, 
Hall ET. 1989. Radiocarbon dating the shroud of Turin. Nature 337:611-5.

Deacon T. 1997. The symbolic species: the co-evolution of language and the brain. New York: Norton.

Dibble HL. 1993. Le Paléolithique moyen récent du Zagros. Bulletin de la Société Préhistorique Française 90(4):307-12.

Dibble HL, Holdaway SJ. 1993. The Middle Paleolithic industries of Warwasi. In: Olszewski DI, Dibble HL, editors. The Paleolithic prehistory of the Zagros-Taurus. Philadelphia: The University Museum, University of Pennsylvania. p 75-100.

Donald M. 1991. Origins of the modern mind. Cambridge: Harvard University Press.

Flannery KV. 1973. The origins of agriculture. Аnпиаl Review of Anthropology 2:271-310.

Gamble, C. 1986 The Palaeolithic settlement of Europe. Cambridge: Cambridge University Press.

Garrod DAE. 1955. The Mugharet el Emireh in lower Galilee: type station of the Emiran industry. Journal of the Royal Anthropological Institute 85:141-62.

Gilman A. 1984. Explaining the Upper Palaeolithic revolution. In: Springs E, editor. Marxist perspectives in archaeology. Cambridge: Cambridge University Press. p 115-26.

Goldberg P, Bar-Yosef O. 1998. Site formation processes in Kebara and Hayonim Caves and their significance in Levantine prehistoric caves. In: Akazawa T, Aoki $\mathrm{K}$, Bar-Yosef O, editors. Neandertals and modern humans in western Asia. New York: Plenum Press. p 107-25.

Golovanova LV, Hoffecker JF, Kharitonov VM, Romanova GP. 1999. Mezmaiskaya Cave: a Neanderthal occupation in the Northern Caucasus. Current Anthropology 40(1):77-86.

Hajdas I, Bonani G, Bodén P, Peteet DM, Mann DH. 1998. Cold reversal on Kodiak Island, Alaska, correlated with the European Younger Dryas by using variations of atmospheric ${ }^{14} \mathrm{C}$ content. Geology 26(11): 1047-50.

Hajdas I, Ivy-ochs S, Bonani G. 1995. Problems in the Extension of the Radiocarbon Calibration Curve (10 $13 \mathrm{Kyr}$ BP). Radiocarbon 37(1):75-9.

Harlan JR. 1977. The origins of cereal agriculture in the Old World. In: Reed CA, editor. Origins of agriculture. The Hague, Paris: Mouton Publishers. p 357-83.

Harlan JR, Zohary D. 1966. Distribution of wild wheat and barley. Science 153:1074-80.

Harris D, editor. 1996a. The origins and spread of agriculture and pastoralism in Eurasia. London: UCL Press.

Harris DR. 1996b. The origins and spread of agriculture and pastoralism in Eurasia: an overview. In: Harris DR, editor. The origins and spread of agriculture and pastoralism in Eurasia. London: UCL Press. p 55273.

Harris DR. 1998a. The origins of agriculture in southwest
Asia. The Review of Archaeology 19(2):5-12.

Harris DR. 1998b. The spread of Neolithic agriculture from the Levant to western central Asia. In: Damania $\mathrm{AB}$, Valkoun J, Willcox G, Qualset $\mathrm{CO}$, editors. The origins of agriculture and crop domestication. Aleppo, Syria: ICARDA. p 65-82.

Harris DR, Hillman GC, editors. 1989. Foraging and farming: the evolution of plant exploitation. London: Unwin Hyman.

Henry DO. 1989. From foraging to agriculture: the Levant at the end of the Ice Age. Philadelphia: University of Pennsylvania Press.

Heun M, Schäfer-Pregl R, Klawan D, Castagna R, Accerbi M, Borghi B, Salamini F. 1997. Site of einkorn wheat domestication identified by DNA fingerprinting. Science 278:1312-4.

Hillman G. 1996. Late Pleistocene changes in wild plantfoods available to hunter-gatherers of the Northern Fertile Crescent: possible preludes to cereal cultivation. In Harris D, editor. The origins and spread of agriculture and pastoralism in Eurasia. London: UCL Press. p 159-203.

Hillman, GC, Colledge S, Harris DR. 1989. Plant food economy during the Epi-Palaeolithic period at Tell Abu Hureyra, Syria: Dietary diversity, seasonality and modes of exploitation. In: Harris DR, Hillman GC, editors. Foraging and farming: the evolution of plant exploitation. London: Unwin Hyman. p 240-66.

Hole F. 1998. The spread of agriculture to the eastern arc of the Fertile Crescent: food for the herders. In: Damania AB, Valkoun J, Willcox G, Qualset CO, editors. The origins of agriculture and crop domestication. Aleppo, Syria: ICARDA. p 83-92.

Karkanas P. 1999. Lithostratigraphy and micromorphology of Theopetra Cave deposits, Thessaly, Greece: some preliminary results. In: Bailey G, Adam E, Panagopoulou E, Perlès $\mathrm{C}$, Zachos $\mathrm{K}$, editors. The palaeolithic archaeology of Greece and adjacent areas. Proceedings of the ICOPAG Conference, Ioannina. London: British School at Athens. p 240-51.

Kislev M. 1997. Early agriculture and paleoecology of Netiv Hagdud. In: Bar-Yosef O, Gopher A, editors. An Early Neolithic village in the Jordan Valley Part I: the archaeology of Netiv Hagdud. Cambridge: Peabody Museum of Archaeology and Ethnology, Harvard University. p 209-36.

Kislev ME, Nadel D, Carmi I. 1992. Epi-Palaeolithic (19,000 B.P.) cereal and fruit diet at Ohalo II, Sea of Galilee, Israel. Review of Palaeobotany and Palynology 71:161-6.

Klein RG. 1995. Anatomy, behavior, and modern human origins. Journal of World Prehistory 9(2):167-98.

Klein RG. 1999. The human career: human biological and cultural origins. 2nd edition. Chicago: University of Chicago Press.

Koumouzelis M, Ginter B, Kozlowski JK, Kazior B, Sobczyk K, Kaczanowska M, Pawlikowski M, Bar- 
Yosef O, Albert RM, Litynska-Zajac M, Stworzewicz E, Wojtal P, Lipecki G, Tomek T, Bochenski ZM, Pazdur A. Cave 1, Klisoura Gorge: the first Aurignacian sequence in Greece. Journal of Field Archaeology. Forthcoming.

Kozlowski JK. 1998. The Middle and the Early Upper Paleolithic around the Black Sea. In: Akazawa T, Aoki $\mathrm{K}$, Bar-Yosef O, editors. Neandertals and modern humans in western Asia. New York: Plenum Press. p 461-82.

Kuhn SL, Bietti A. The Late Middle and Early Upper Paleolithic in Italy. In Bar-Yosef O, Pilbeam D, editors. The geography of Neandertals and modern humans in Europe and the greater Mediterranean. Cambridge: Peabody Museum Press. Forthcoming.

Kuhn SL, Stiner MC, Güleç E. 1999. Initial Upper Palaeolithic in south-central Turkey and its regional context: a preliminary report. Antiquity 73(281):505-17.

Kyparissi-Apostolika N. 1999. The Palaeolithic deposits of Theopetra Cave in Thessaly (Greece). In: Bailey G, Adam E, Panagopoulou E, Perlès C, Zachos K. The Palaeolithic archaeology of Greece and adjacent areas. Proceedings of the ICOPAG Conference, Ioannina. London: British School at Athens. p 232-9.

Legge T. 1996. The beginning of caprine domestication in Southwest Asia. In: Harris D, editor. The origins and spread of agriculture and pastoralism in Eurasia. London: UCL Press. p 238-62.

Lemcke G, Sturm M. 1997. "218 O and Trace element measurements as proxy for the reconstructions of climate changes at lake Van (Turkey): preliminary results. In: Dalfes HN, Kukla G, Weiss H, editors. Third Millennium BC climate change and Old World collapse. Berlin: Springer-Verlag. p 653-78.

Libby WF. 1952. Radiocarbon dating. 1st edition. Chicago: University of Chicago Press.

Marino BD, DeNiro MJ. 1987. Isotopic analysis or archaeobotanicals to reconstruct past climates: effects of activities associated with food preparation on carbon, hydrogen and oxygen isotope ratios of plant cellulose. Journal of Archaeological Science 14:537-48.

Marino BD, McElroy MB. 1991. Isotopic composition of atmospheric $\mathrm{CO}_{2}$ inferred from carbon in $\mathrm{C} 4$ plant cellulose. Nature 349:127-31.

Marks A, editor. 1983. Prehistory and paleoenvironments in the Central Negev, Israel. Volume III. Dallas: Southern Methodist University Press.

Marks AE. 1993. The early Upper Paleolithic: the view from the Levant. In: Knecht H, Pike-Tay A, White R. Before Lascaux: the complete record of the early Upper Paleolithic. Boca Raton: CRC Press. p 5-22.

Marks AE, Chabai VP, editors. 1998. The Middle Paleolithic of Western Crimea. Volume 1. Liège: ERAUL.

Marshack A. 1972. The roots of civilization: the cognitive beginnings of man's first art, symbol, and notation. New York: McGraw-Hill.

Marshack A. 1997. "Paleolithic image making and sym- boling in Europe and the Middle East: A comparative review," In: Conkey M, Soffer O, Stratmann D, Jablonski NG, editors. Beyond art: Pleistocene image and symbol. San Francisco: Memoirs of California Academy of Sciences. p 53-91.

Mayewski PA, Meeker LD, Whitlow S, Twickler MS, Morrison MC, Alley RB, Bloomfield R, Taylor K. 1993. The atmosphere during the Younger Dryas. Science 261:195-7.

Mayewski PA, Twickler MS, Whitlow SI, Meeker LD, Yang Q, Thomas J, Kreutz K, Grootes PM, Morse DL, Steig EJ. 1996. Climate change during the last deglaciation in Antarctica. Science 272:1636-8.

McBurney CBM. 1967. The Haua Fteah (Cyrenaica) and the Stone Age of the south-east Mediterranean. Cambridge: Cambridge University Press.

Meadow RH. 1998. Pre- and Proto-Historic Agricultural and Pastoral Transformations in Northwestern South Asia. The Review of Archaeology 19(2):12-22.

Mellars P. 1989. Technological changes at the MiddleUpper Palaeolithic transition: Economic, social and cognitive perspectives. In: Mellars $\mathrm{P}$, Stringer C, editors. The human revolution: behavioural and biological perspectives on the origins of modern humans. Edinburgh: Edinburgh University Press. p 338-65.

Mellars P. 1996a. The Neanderthal legacy: an archaeological perspective from Western Europe. Princeton: Princeton University Press.

Mellars P 1996b. Symbolism, language, and the Neanderthal mind. In: Mellars P, Stringer C, editors. Modelling the early human mind. Cambridge: McDonald Institute of Archaeological Research. p 15-32.

Mellars P, Otte M, Straus L, Zilhão J, D’Errico F. 1999. The Neanderthal problem continued. CA Forum on Theory in Anthropology. Current Anthropology 40(3): 341-64.

Mellars P, Tixier J. 1989. Radiocarbon accelerator dating of Ksar Aqil (Lebanon) and the chronology of the Upper Paleolithic sequence in the Middle East. Antiquity 63:761-8.

Miller NF. 1992. The Origins of Plant Cultivation in the Near East. In: Cowan CW, Watson PJ, editors. The origins of agriculture: an international perspective. Washington DC: Smithsonian Institution Press. p 39_ 58 .

Miller NF. 1997. The macrobotanical evidence for vegetation in the Near East, c. 18,000/16,000 BC to 4,000 BC. Paléorient 23(2):197-208.

Mithen S. 1996. The Prehistory of the mind: a search for the origins of art, religion, and science. London: Thames and Hudson.

Moore AMT, Hillman GC. 1992. The Pleistocene to Holocene transition and human economy in southwest Asia: the impact of the Younger Dryas. American Antiquity 57(3):482-94.

Moore AMT, Gowlett JAJ, Hedges REM, Hillman GC, Legge AJ, Rowley-Conwy PA. 1986. Radiocarbon ac- 
celerator (AMS) dates for the Epipaleolithic settlement at Abu Hureyra, Syria. Radiocarbon 28(3): 1068-76.

Newcomer MH. 1970. The chamfered pieces from Ksar Akil. Bulletin of the Institute of Archaeology 8,9:17791.

Ohnuma K. 1988. Ksar Akil, Lebanon: a technological study of the earlier Upper Palaeolithic levels at Ksar Akil. Volume III: Levels XXV-XIV. Oxford: British Archaeological Reports.

Ohnuma K, Bergman CA. 1990. A technological analysis of the Upper Palaeolithic Levels (XXV-VI) of Ksar Akil, Lebanon. In: Mellars P, editor. The emergence of modern humans. Edinburgh: Edinburgh University Press. p 91-138.

Otte M, editor. 1998. Préhistoire d'Anatolie: genèse de deux mondes. Anatolian prehistory: at the crossroads of two worlds. Volume II. Liège: ERAUL.

Otte M, Yalçinkaya I, Taskiran H, Kozlowski JK, BarYosef O, Noiret P. 1995. The Anatolian Middle Paleolithic. Journal of Anthropological Research 51:28799.

Pfeiffer JE. 1982. The creative explosion: an inquiry into the origins of art and religion. New York: Harper and Row.

Quintana-Murci L, Semino O, Bandelt H-J, Passerino G, McElreavey K, Santachiara-Benerecetti AS. 1999. Genetic evidence of an early exit of Homo sapiens sapiens from Africa through eastern Africa. Nature Genetics 23(4):437-41.

Raposo L, Santonja M. 1995. The earliest occupation of Europe: the Iberian peninsula. In: Roebroeks W, Van Kolfschoten T, editors. The earliest occupation of Europe. Leiden: University of Leiden. p 7-25.

Renfrew C. 1973. Before civilization: the radiocarbon revolution and prehistoric Europe. London: Jonathan Cape.

Renfrew C. 1987. Archaeology and language: the puzzle of Indo-European origins. Cambridge: Cambridge University Press.

Rink WJ, Lee HK, Rees-Jones J, Goodger KA. 1998. Electron spin resonance (ESR) and mass spectrometric U-series (MSUS) dating of teeth in Crimean Paleolithic site: Starosele, Kabazi II, and Kabazi V. In: Marks AE, Chabai VP, editors. The middle Paleolithic of western Crimea. Volume 1. Liège: ERAUL. p 32340.

Roberts N, Wright HE Jr. 1993. Vegetational, lake level, and climatic history of the Near East and southwest Asia. In: Wright JE Jr. Kutzbach JE, Web T III, Ruddiman F, Street-Perrott FA, Bartlein PJ, editors. Global changes since the last glacial maximum. Minneapolis: University of Minnesota Press. p 194-220.

Rosenberg M, Nesbitt RM, Redding RW, Strasser TF. 1995. Hallan Çemi Tepesi: some preliminary observations concerning early Neolithic subsistence behaviors in eastern Anatolia. Anatolica 21:1-12.
Rossignol-Strick M. 1995. Sea-land correlation of pollen records in the eastern Mediterranean for the glacial-interglacial transition: biostratigraphy versus radiometric time-scale. Quaternary Science Reviews 14:893915.

Rossignol-Strick M. 1997. Paléoclimat de la Méditerranée orientale et de l'Asie du Sud-Ouest de 15000 à 6000 BP. Paléorient 23(2):175-86.

Sage RF. 1995. Was low atmospheric $\mathrm{CO}_{2}$ during the Pleistocene a limiting factor for the origin of agriculture? Global Change Biology 1:93-106.

Sherratt A. 1997. Climatic cycles and behavioural revolutions: the emergence of modern humans and the beginning of farming. Antiquity 71:271-87.

Smith AB. 1998. Keeping people on the periphery: the ideology of social hierarchies between hunters and herders. Journal of Anthropological Archaeology 17(2):201-15.

Smith FH, Trinkaus E, Pettitt PB, Karavanic I, Paunovic M. 1999. Direct radiocarbon dates for Vindija G1 and Velika Pecina Late Pleistocene hominid remains. Proceedings of the National Academy of Sciences 96(22): 12281-6.

Smith PEL. 1986. Paleolithic archaeology in Iran. Philadelphia: The American Institute of Iranian Studies and the University Museum, University of Pennsylvania

Solecki RS. 1963. Prehistory in Shanidar Valley, northern Iraq. Science 139:179-93.

Solecki RS. 1964. Shanidar Cave, a Late Pleistocene site in northern Iraq. Report of the VIth International Congress on Quaternary, Warsaw, 1961. p 413-23.

Solecki RS, Solecki RL. 1993. The pointed tools from the Mousterian occupations of Shanidar Cave, Northern Iraq. In: Olszewski DI, Dibble HL, editors. The Paleolithic prehistory of the Zagros-Taurus. Philadelphia: The University Museum, University of Pennsylvania. p 119-46.

Straus LG. 1996. Continuity or rupture; convergence or invasion; adaptation or catastrophe; mosaic or monolith: views on the Middle to Upper Paleolithic transition in Iberia. In: Carbonell $\mathrm{E}$, Vaquero $\mathrm{M}$, editors. The last Neandertals, the first anatomically modern humans. Tarragona: Universitat Rovira i Virgili. p 20318.

Straus LG. 1997. The Iberian situation between 40,000 and 30,000 BP in light of European models of migration and convergence. In: Clark GA, Willermet CM, editors. Conceptual issues in modern humans origins research. New York: Aldine de Gruyter. p 235-52.

Stringer C, Gamble C. 1993. In search of the Neanderthals. London: Thames and Hudson.

Stuiver M, Long A, Kra RS, editors. 1993. Calibration 1993. Radiocarbon 35(1):1-244.

Stuiver M, Reimer PJ, Bard E, Beck JW, Burr GS, Hughen KA, Kromer B, McCormac G, Van der Plicht J, Spurk M. 1998. INTCAL98 radiocarbon age calibra- 
tion, 24,000-0 cal BP. Radiocarbon 40(3):1041-84.

Svoboda J, Simán K. 1989. The middle-upper Paleolithic transition in southeastern central Europe (Czechoslovakia and Hungary). Journal of World Prehistory 3: 283-322.

Taylor RE 1997 Radiocarbon Dating. In: Taylor RE, Aitken MJ editors. Chronometric dating in archaeology. New York: Plenum Press. p 65-96.

Uerpmann HP. 1989. Problems of archaeo-zoological research in Eastern Arabia. Oman Studies LXIII:163-8.

Valladas H, Joron JL, Valladas G, Arensburg B, BarYosef O, Belfer-Cohen A, Goldberg P, Laville H, Meignen L, Rak Y. 1987. Thermoluminescence dates for the Neanderthal burial site at Kebara in Israel. $\mathrm{Na}$ ture 330:159-60.

Van Andel TH. 1998. Middle and Upper Palaeolithic environments and the calibration of ${ }^{14} \mathrm{C}$ dates beyond 10,000 BP. Antiquity 72(275):26-33.

Van Andel TH, Runnels CN. 1995. The earliest farmers in Europe. Antiquity 69(264):481-500.

Van der Plicht J. 1999. Radiocarbon calibration for the Middle/Upper Palaeolithic: a comment. Antiquity 73(279):119-123.

Van der Plicht J, Van der Wijk A, Bartstra GJ. 1989. Uranium and thorium in fossil bones: activity ratios and dating. Applied Geochemistry 4:339-42.

Van Peer P. 1998. The Nile Corridor and the Out-of-Africa model: an examination of the archaeological record. Current Anthropology 39: supplement, 1998 June. S115-S140.

Van Zeist W. 1986. Some aspects of Early Neolithic plant husbandry in the Near East. Anatolica 15:49-67.

Van Zeist W, Bakker-Herres JAH. 1986. Archaeobotanical Studies in the Levant. III. Late Paleolithic Mureybet. Palaeohistoria 26:171-99.

Van Zeist W, Bottema S. 1991. Late Quaternary vegetation of the Near East. Weisbaden: Dr. Ludwig Reichert Verlag.

Volkman P. 1983. Boker Tachtit: core reconstructions. In: Marks AE, editor. Prehistory and paleoenvironments in the Central Negev, Israel. Dallas: Southern Methodist University Press. p 127-90.

Wetterstrom W. 1993. Foraging and farming in Egypt: the transition from hunting and gathering to horticulture in the Nile valley. In: Shaw T, Sinclair P, Andah $\mathrm{B}$, Okpoko A, editors. The archaeology of Africa: food, metals and towns. London: Routledge. p 165226.

Wetterstrom W. 1998. The origins of agriculture in Africa: with particular reference to sorghum and pearl millet. Review of Archaeology 19(2):30-47.

White R. 1989. Production complexity and standardiza- tion in early Aurignacian bead and pendant manufacture: evolutionary implications. In: Mellars P, Stringer $\mathrm{C}$, editors. The human revolution: behavioural and biological perspectives on the origins of modern humans. Edinburgh: Edinburgh University Press. p 36690.

White R. 1997. Substantial acts: from materials to meaning in Upper Paleolithic representation. In: Conkey MW, Soffer O, Stratmann D, Jablonski HG, editors. Beyond art: Pleistocene image and symbol. San Francisco: Memoirs of the California Academy of Sciences. p 93-121

Wright HE Jr. 1993. Environmental determinism in Near Eastern prehistory. Current Anthropology 34(4):45869.

Yakir D, Issar A, Gat J, Adar E, Trimborn P, Lipp J. 1994. ${ }^{13} \mathrm{C}$ and ${ }^{18} \mathrm{O}$ of wood from the Roman siege rampart in Masada, Israel (AD 70-73): evidence for a less arid climate for the region. Geochimica et Cosmochimica Acta 58(16):3535-9.

Yalçinkaya I, Otte M, Bar-Yosef O. Kozlowski J, Léotard JM, Taskiran H. 1993. The excavations at Karain Cave, south-western Turkey: an interim report. In: Olszewski DI, Dibble HL, editors. The Paleolithic prehistory of the Zagros-Taurus. Philadelphia: The University Museum of the University of Pennsylvania. p 100-6.

Zilhão J, D'Errico F. 1999a. Reply in Mellars et al.: the Neanderthal problem, continued. CA Forum on Theory in Anthropology. Current Anthropology 40(3): 355-64.

Zilhão J, D'Errico F. 1999b. The chronology and taphonomy of the earliest Aurignacian and its implications for the understanding of Neanderthal extinction. Journal of World Prehistory 13(1):1-68.

Zohary D. 1989. Domestication of the Southwest Asian Neolithic crop assemblage of cereals, pulses, and flax: the evidence from the living plants. In: Harris DR, Hillman GC, editors. Foraging and farming: the evolution of plant exploitation. London: Unwin Hyman. $\mathrm{p}$ 358-73.

Zohary D, Hopf M, editors. 1994. Domestication of plants in the old world. 2nd edition. Oxford: Clarendon Press.

Zohary M. 1973. Geobotanical foundations of the Middle East. Stuttgart: Springer Verlag.

Zubrow E. 1989. The demographic modelling of Neanderthal extinction. In: Mellars P, Stringer C, editors. The human revolution: behavioural and biological perspectives in the origins of modern humans. Edinburgh: Edinburgh University Press. p 212-31. 